 \\ WHAT'S NEW IN POLITICAL SCIENCE? titles!
}

Socratic and Platonic Political Philosophy Practicing a Politics of Reading Christopher P. Long

\$90.00: Hb: 978-1-107-04035-9: 240 pp.

\section{Compulsory Voting}

For and Against

Jason Brennan and

Lisa Hill

\$85.00: Hb: 978-1-107-04151-6: 240 pp. \$29.99: Pb: 978-1-107-61392-8

\section{Statistical Modeling} and Inference for Social Science

Sean Gailmard

Analytical Methods for

Social Research

\$75.00: Hb: 978-1-107-00314-9: 384 pp.

\section{Revolutionary Writings}

Reflections on the Revolution in France and the First Letter on a Regicide Peace

\section{Edmund Burke}

Edited by lain Hampsher-Monk Cambridge Texts in the History of Political Thought

\$80.00: Hb: 978-0-521-84393-5: 419 pp. \$27.99: Pb: 978-0-521-60509-0

\section{Third Edition}

\section{American Government}

Enduring Principles,

Critical Choices

Marc Landy and

Sidney M. Milkis

\$75.00: Pb: 978-1-107-65002-2: 424 pp.

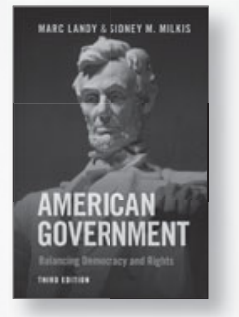

Prices subject to change.
Political Journalism in Comparative Perspective

Erik Albæk, Arjen van Dalen, Nael Jebril, and

Claes de Vreese

Communication, Society and Politics

\$85.00: Hb: 978-1-107-03628-4: 264 pp. \$28.99: Pb: 978-1-107-67460-8

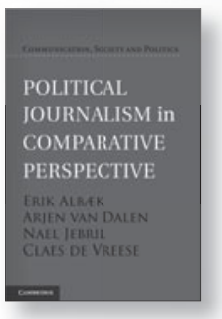

Why Electoral Integrity Matters

Pippa Norris

\$85.00: Hb: 978-1-107-05280-2: 312 pp. \$29.99: Pb: 978-1-107-68470-6

\section{The Politics of}

Representation

in the Global Age

Identification, Mobilization, and Adjudication

Edited by Peter A. Hall, Wade Jacoby, Jonah Levy, and

Sophie Meunier

\$90.00: Hb: 978-1-107-03776-2: 264 pp \$32.99: Pb: 978-1-107-61189-4

\section{Counting Islam}

Religion, Class, and

Elections in Egypt

Tarek Masoud

Problems of International Politics \$80.00: Hb: 978-1-107-00987-5: 256 pp. \$29.99: Pb: 978-0-521-27911-6: 265 pp.

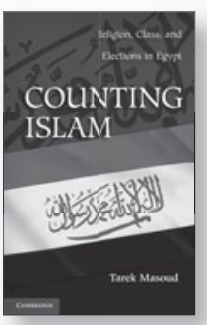

\section{Cambridge Studies in International Relations}

The Status of Law in World Society

Meditations on the Role and Rule of Law

Friedrich Kratochwil

\$95.00: Hb: 978-1-107-03728-1: 323 pp.

\$34.99: Pb: 978-1-107-68107-1

\section{Global Shell Games}

Experiments in Transnational

Relations, Crime, and Terrorism

Michael G. Findley,

Daniel L. Nielson, and

Jason Sharman

\$90.00: Hb: 978-1-107-04314-5: $271 \mathrm{pp}$.

\$32.99: Pb: 978-1-107-63883-9

\section{Democratic Militarism}

Voting, Wealth, and War

Jonathan D. Caverley

\$85.00: Hb: 978-1-107-06398-3: 326 pp.

\$29.99: Pb: 978-1-107-66737-2

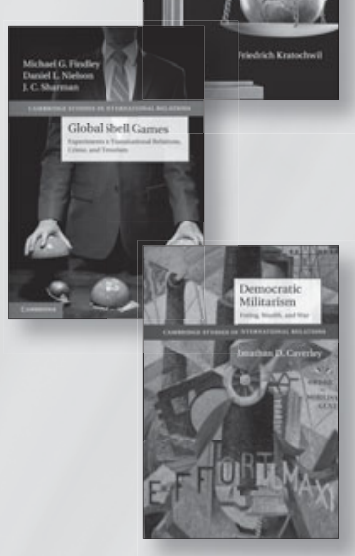

\section{Status in}

\section{World Politics}

Edited by T. V. Paul,

Deborah Welch Larson, and William C. Wohlforth

\$90.00: Hb: 978-1-107-05927-6: 328 pp. \$32.99: Pb: 978-1-107-62929-5

\section{Peaceland}

Conflict Resolution and the Everyday Politics of International Intervention

Séverine Autesserre

\$85.00: Hb: 978-1-107-05210-9: 360 pp. \$29.99: Pb: 978-1-107-63204-2

\section{The Outbreak}

of the First World War

Structure, Politics, and

Decision-Making

Edited by Jack S. Levy and

John A. Vasquez

\$90.00: Hb: 978-1-107-04245-2: 320 pp. \$34.99: Pb: 978-1-107-61602-8
The Rise and Fall of Ireland's Celtic Tiger Liberalism, Boom and Bust Seán Ó’Riain

\$85.00: Hb: 978-1-107-00982-0: 324 pp. \$32.99: Pb: 978-0-521-27905-5

Social Choice and Legitimacy

The Possibilities of Impossibility John W. Patty and Elizabeth Maggie Penn

Political Economy of Institutions and Decisions

\$80.00: Hb: 978-0-521-19101-2: 224 pp. \$28.99: Pb: 978-0-521-13833-8

\section{The Awakening of} Muslim Democracy Religion, Modernity, and the State Jocelyne Cesari \$90.00: Hb: 978-1-107-04418-0: 400 pp. \$32.99: Pb: 978-1-107-66482-1 


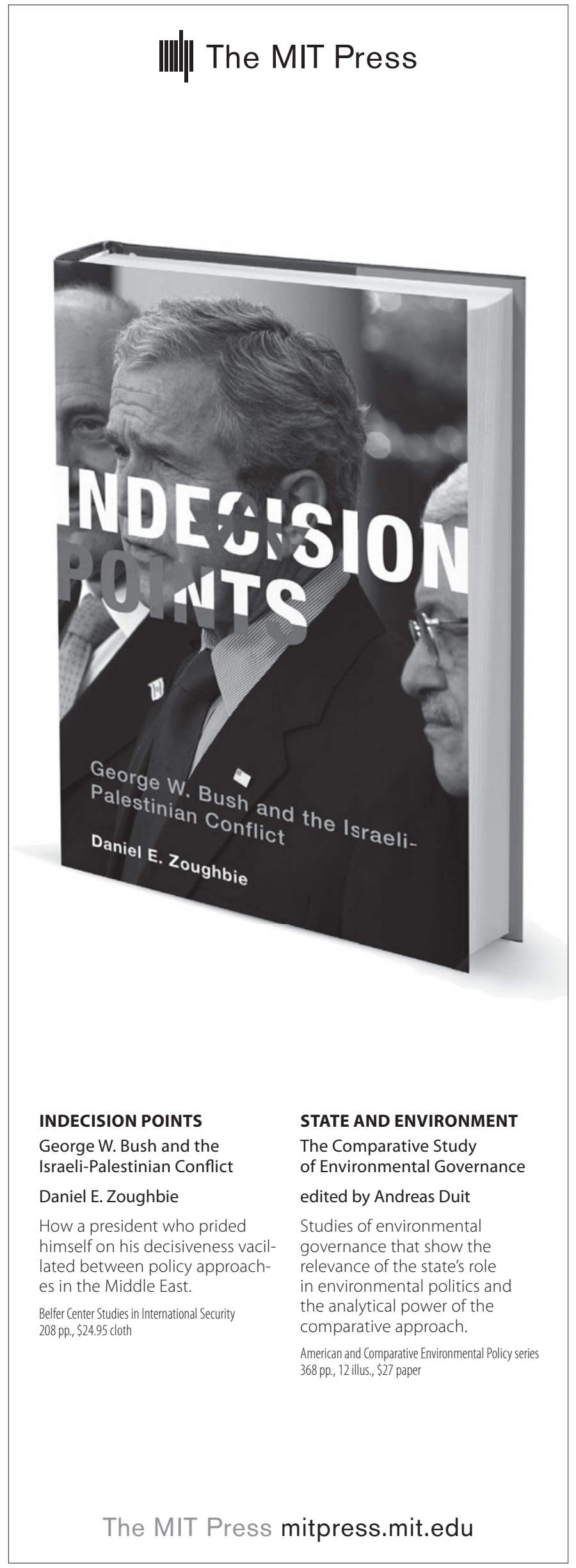



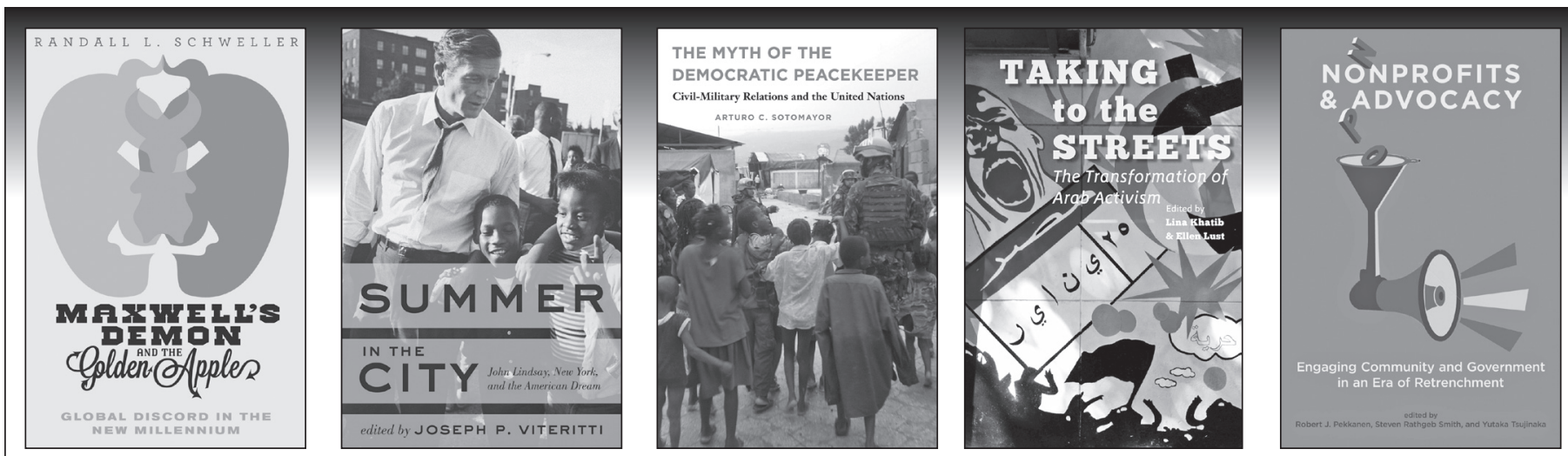

\section{Maxwell's Demon and the Golden Apple}

Global Discord in the New Millennium Randall L. Schweller

"With his typical verve, Schweller explains why and how the concept of entropy illuminates current and coming world politics."

—Robert Jervis, author of System Effects

\$24.95 cloth/ebook

\section{Summer in the City}

John Lindsay, New York, and

the American Dream

edited by Joseph P. Viteritti

"The best volume about Mayor John Lindsay ever published."--Richard Flanagan, College of Staten Island, CUNY

\$29.95 paper/ebook

\section{Pain}

A Political History

Keith Wailoo

"In this remarkable book, Wailoo explores the long American struggle over pain."

- James A. Morone, author of Hellfire Nation $\$ 29.95$ cloth/ebook

\section{Doctors Without Borders}

Humanitarian Quests, Impossible Dreams of Médecins Sans Frontières

Renée C. Fox

$\$ 29.95 \mathrm{cloth} / \mathrm{ebook}$

\section{Noncommunicable Diseases in the Developing World \\ Addressing Gaps in Global \\ Policy and Research edited by Louis Galambos and Jeffrey L. Sturchio \\ \$34.95 paper/ebook}

\section{Why Mars}

NASA and the Politics of Space Exploration W. Henry Lambright

$\$ 49.95 \mathrm{cloth} / \mathrm{ebook}$

\section{Protesting Affirmative Action}

The Struggle over Equality after the Civil Rights Revolution Dennis Deslippe

\$29.95 paper/ebook

\section{The Myth of the}

\section{Democratic Peacekeeper}

Civil-Military Relations and the United Nations Arturo C. Sotomayor

"This myth-shattering book will be the standard reference on Latin American peacekeepers for years to come."-David Pion-Berlin, University of California, Riverside

$\$ 39.95$ paper/ebook

\section{Taking to the Streets}

The Transformation of Arab Activism edited by Lina Khatib and Ellen Lust

"An authoritative account of events linked to the Arab Spring."

—Amaney A. Jamal, Princeton University \$29.95 paper/ebook

\section{Democratization and}

\section{Authoritarianism in the Arab World} edited by Larry Diamond and Marc F. Plattner

Three years after the first mass protests of the Arab Spring, senior scholars weigh in on how democracy is faring.

\$34.95 paper/ebook

\section{Track-Two Diplomacy toward an Israeli-Palestinian Solution, 1978-2014 \\ Yair Hirschfeld}

An insider's account of the evolution of IsraeliPalestinian negotiations.

Woodrow Wilson Center Press \$44.95 paper

\section{Violence after War}

Explaining Instability in Post-Conflict States Michael J. Boyle

"Fills a large void in our understanding of postconflict violence."

—Monica Duffy Toft, University of Oxford $\$ 69.95$ cloth/ebook

\section{Gender and the Long Postwar}

The United States and the Two Germanys, 1945-1989 edited by Karen Hagemann and Sonya Michel

Woodrow Wilson Center Press $\$ 49.95$ paper

\section{Nonprofits and Advocacy}

Engaging Community and Government in an Era of Retrenchment edited by Robert J. Pekkanen, Steven Rathgeb Smith, and Yutaka Tsujinaka Does nonprofit mean nonpolitical? \$44.95 paper/ebook

\section{Clientelism, Social Policy, and the Quality of Democracy edited by Diego Abente Brun and Larry Diamond}

Social scientists explore how political clientelism works and evolves in the context of modern developing democracies.

$\$ 34.95$ paper/ebook

\section{Rivalry and Alliance Politics in Cold War Latin America Christopher Darnton \\ "Indispensable reading." \\ -O.A. Westad, author of The Global Cold War \$44.95 paper/ebook}

\section{Seizing Power}

The Strategic Logic of Military Coups Naunihal Singh

"The best piece of social science research on military coups so far."

—Stathis Kalyvas, Yale University $\$ 59.95$ cloth/ebook

\section{Africa Consensus}

New Interests, Initiatives, and Partners Ludger Kühnhardt

Woodrow Wilson Center Press \$44.95 paper

\section{Great Powers, Small Wars}

Asymmetric Conflict since 1945

Larisa Deriglazova

Woodrow Wilson Center Press $\$ 60.00$ cloth

\section{jh JOHNS HOPKINS \\ UNIVERSITY PRESS}

